\title{
EDITORIAL
}

\section{JIEM: A New Exciting Journey into the Research of Industrial Engineering and Management}

\author{
Vicenc Fernandez; Pep Simo; Jose M. Sallan; Mihaela Enache \\ Universitat Politècnica de Catalunya (SPAIN) \\ vicenc.fernandez@jiiem.org; pep.simo@jiem.org;jsallan@jiem.org; mihaela.enache@jiem.org
}

\section{Welcome to the inaugural issue of JIEM}

First of all, we are pleased to introduce this first and inaugural issue of the first volume of the Journal of Industrial Engineering and Management (JIEM). JIEM is an international journal that proposes and fosters discussion on the theory and application in all areas of industrial engineering and industrial management, including (but not limited to) production, logistics, operation research, quality, technology, information systems, project management, as well as regional development, industrial economics, management, organizational behaviour, finance, accounting and marketing.

The main objective of the journal is to provide a platform for interaction among professionals, academics, researchers, practitioners and policymakers in order to facilitate the dissemination of information, knowledge and new developments of the broad field of industrial engineering and management. In order to achieve this goal, JIEM publishes papers reporting the results of original empirical research, which can adopt confirmatory (quantitative) or explanatory (mainly qualitative) methodological approaches. Besides, theoretical essays that enhance the building or extension of theoretical approaches are also welcome.

JIEM has initially been conceived as a semestral journal, exclusively on-line, and following an open access policy. Special issues dedicated to important topics in industrial engineering and industrial management will also be published regularly. 
JIEM selects the articles to be published with a double bind, peer review system, following the practices of good scholarly journals. To maintain a high level of quality in the journal, we guarantee that any submission will be handled by independent editors and blind reviewers to ensure the independence and fairness in the review process. Moreover, we promise to work to improve and extend our editorial review board to provide you excellent reviews that will help you to further develop your thinking and ideas.

One of the most important points distinguishing JIEM from similar academic publications is that our journal requires a relatively short period to communicate the overall result of the evaluation (accepted, accepted with modifications or rejected), including the reviewer's comments and without giving up a high quality level in the process of evaluation. We believe that long periods of time in the process of evaluation and publication (some times years) decrease the value of the research and the value of authors' effort. For this reason and considering the importance of a fast dissemination of scholarly knowledge without delay to professionals, academics, researchers and practitioners, we promise to give the initial decision in a period of time less than eight weeks. Besides, we guarantee that the accepted articles will be published in the following issue of the journal.

\section{Invitation to J IEM}

JIEM editors welcome authors from all over the world, including Europe, America, Asia, and Africa and invite them to forward their contributions in the areas of industrial engineering and management for possible publication in JIEM.

JIEM includes contributions, but not limited to, in the following fields:

- Industrial Economics and Regional Development

- Management, Organizational Behaviour and Human Resources

- Finance, Accounting and Marketing in Industrial Sectors

- Information Systems, Technology and Communication

- Production, Logistics, Quality, and Operational Research

- Education, Training and Professional Skills 
Moreover, we invite you to propose special issues on specific themes of industrial engineering and management. If you are interested in proposing a special issue for JIEM, please email us at editor@jiem.org.

\section{Call for reviewers}

We believe that the quality level of a journal depends on the quality of its articles. As a peer-reviewed journal, the quality of the articles of JIEM is enhanced by the evaluation skills of its reviewers. The comments, suggestions, criticisms and judgments of the reviewers are essential factors in assisting the Editors in their decision of publishing a manuscript. Nowadays, JIEM has a pool of knowledgeable and well-qualified reviewers (more than thirty) for evaluating the manuscripts. However, considering the broad range of fields on industrial engineering and management, JIEM is expanding its reviewer pool and invites interested professionals, academics, researchers and practitioners to assess papers for potential publication. If you are interested in reviewing for JIEM, please access the JIEM intranet and apply for membership as a reviewer in the journal.

\section{Join JIEM}

Finally, we encourage readers and authors to sign up for the publishing notification service for this journal. And remember that your comments are always welcome, as well as original paper submissions and proposals for special issues. Thank you for your interest in our new publication and, once again, welcome!

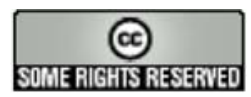

Article's contents are provided on a Attribution-Non Commercial 3.0 Creative commons license. Readers are allowed to copy, distribute and communicate article's contents, provided the author's and Journal of Industrial Engineering and Management's names are included. It must not be used for commercial purposes. To see the complete license contents, please visit http://creativecommons.org/licenses/by-nc/3.0/. 